
\title{
25 Research Square \\ In Vitro Evaluation of Herbicides on Beneficial and Pathogenic Microorganisms
}

Thumu Venkateswara Reddy ( $\nabla$ thumuvenkat333@gmail.com )

Kerala Agricultural University

Meera V. Menon

Cashew Research Station

Anita Cherian K.

Kerala Agricultural University

Sindhu P.V.

Kerala Agricultural University

Karthika Mohan

Kerala Agricultural University

Daly George

Kerala Agricultural University

\section{Research Article}

Keywords: Bioagents, pathogens, Pseudomonas, Pyricularia, Rhizoctonia, Trichoderma

Posted Date: December 20th, 2021

DOI: https://doi.org/10.21203/rs.3.rs-1141995/v1

License: (c) (i) This work is licensed under a Creative Commons Attribution 4.0 International License.

Read Full License 


\section{Abstract}

An experiment was conducted in the laboratory to evaluate the effect of herbicides on beneficial and pathogenic microorganisms. Eighteen treatments included six herbicides at three different doses viz., cyhalofop-butyl (80, 160 and 240 ppm), cyhalofop-butyl + penoxsulam (150, 300 and 450 ppm), bispyribac-sodium (25, 50 and 75 ppm), fenoxaprop-p-ethyl (60, 12 and 180 ppm), carfentrazone-ethyl $(20,40$ and $60 \mathrm{ppm})$ and chlorimuron-ethyl + metsulfuron-methyl $(4,8$ and $12 \mathrm{ppm})$ evaluated on beneficial microbial bioagents (Trichoderma viride and Pseudomonas fluorescens) and pathogenic microorganisms (Rhizoctonia solani, Pyricularia oryzae and Xanthomonas oryzae pv. oryzae). Results revealed that bispyribac-sodium and cyhalofop-butyl + penoxsulam had greatest inhibitory effect on pathogenic microorganisms Rhizoctonia solani (47.76 and 54.40\%) and Pyricularia oryzae (49.07 and $61.12 \%)$, but showed no effect on Xanthomonasoryzaepv. oryzae, and were less harmful to biocontrol agents Trichoderma viride and Pseudomonas fluorescens at recommended doses, which were effective in control of broad spectrum of weed flora in rice ecosystem.

\section{Introduction}

The rice crop is infected with 50 diseases and disorders, comprising six bacterial, 21 fungal, four nematode, 12 viral, and seven other diseases and disorders [18, 20, 21, 22-59]. Rice blast, brown spot, bacterial leaf blight and leaf streak, sheath blight, sheath rot, Fusarium wilt or Bakanae, stem rot, Tungro virus, fake smut, and post-harvest diseases are among the most common diseases [50]. These diseases are believed to have caused a worldwide yield drop of 14-18\% [33].

Plant diseases triggered by soil-borne pathogens are reported to be affected by herbicides [4, 23]. Several scientists have observed that plants have an herbicidal effect on plant diseases [3,5-27]. Herbicides not only kill the target weeds, but they also have an unintended effect on plant diseases in the soil, which can be both direct and indirect. [60] Revealed that a low dosage of herbicides enhances pathogen development in vitro. As a result, in both the direct and indirect effects of herbicides on plant diseases, dose is critical. Herbicides affect the plant-pathogen relationship by affecting the plant or pathogen, as well as the soil organisms around it. Herbicides influence plant diseases by either altering the pathogen's virulence or affecting the host plant's level of resistanc [29].

Rice blast is an infectious fungal disease produced by a filamentous ascomycete fungus (Pyricularia oryzae) that is found in more than 85 countries throughout the world $[13,49]$. Numerous rice blast outbreaks were reported in various regions of the globe, leading to huge production losses ranging from 50 to 90 per cent of the predicted harvest in certain places [2,10,31-45]. During normal circumstances, yield losses due to blast varied from 1 to 50 per cent in diverse rice-growing regions around the world, depending on the cultivars used and the weather conditions [15]. Rice blast fungus mycelial growth was suppressed by Trichoderma spp. [37]. 
Rice sheath blight (Rhizoctonia solani) is a severe plant disease that causes output losses of up to $54.3 \%$ in rice-growing areas of India [9]. $R$. solani is a soil-borne plant pathogen with a diverse host range that frequently causes damage to legume crops in rice rotations $[46,62]$. Trifluralin and butralin at concentrations of $5,50,100,500$, and $1000 \mathrm{mg} / \mathrm{I}$ reduced Rhizoctonia solani fungal isolates [1]. According to [28] pendimethalin, alachlor, and quizalofop-p-ethyl completely inhibited the growth of $R$. solani. [41]'s findings highlight the additional benefits of disease suppression that must be obtained through the use of herbicide mixtures, penoxsulam + cyhalofop butyl 6\% OD and bispyribac sodium + metamifop $14 \% \mathrm{SE}$, due to their inhibitory effect on $R$. solani growth, and their efficacy in weed control, and also used in integrated pest and disease management programmes.

Bacterial blight caused by Xanthomonas oryzae pv. oryzae [56] is a severe danger to rice growers in irrigated, deep water, rainfed, temperate, tropical, and subtropical areas around the world [32]. This devastating disease has now established itself as a significant factor affecting rice crops, particularly in Southeast Asia. Since the widespread cultivation of dwarf high yielding cultivars, production losses of 1182 per cent have been seen in the Philippines, India, and Indonesia [36, 53].

Biocontrol agents have been found to be both environmentally safe and effective against a variety of plant infections. Increased chemical use in rice farming has negative consequences for the ecology, particularly for useful predators and parasitoids [8].

Trichoderma viride is a possible biocontrol agent for a variety of diseases found in soil and seeds [38]. It is one of the most effective agents for biological control of diseases due to its antagonistic action on inimical organisms [16].Tolerance to regularly used pesticides improved the efficacy of biocontrol agents like $T$. viride and enhanced their application range according to [11], and in some cases, they promoted its growth. Treatment with $50 \mathrm{ppm}$ butachlor resulted in an increase in T. viride CFU 24 hours after treatment, according to [42]. [34] found that $T$. viride in the soil had the highest level of atrazine inactivation and was capable of inactivating-detoxicating simazine.

Pseudomons fluorescens is one of the most important bacterial biocontrol agents because it is particularly successful in root colonisation and biocontrol activity by creating antifungal metabolites such as antibiotics, hydrogen cyanide, and siderophores [35]. [19] Reported that Pseudomonas fluorescens strain IM-4 was capable of degrading imazethapyr. [58] Stated that Pseudomonas fluorescens SMF1 strain was resistant to 2, 4-D.

With this background, in vitro experiments were carried out to find out the non-target effect of six herbicides including two premix herbicides viz., cyhalofop-butyl, bispyribac-sodium, fenoxaprop-p-ethyl, carfentrazone-ethyl, cyhalofop-butyl + penoxsulam and chlorimuron-ethyl + metsulfuron-methyl in rice.

\section{Methods}

In vitro evaluation of herbicides against beneficial and pathogenic microorganismsin rice ecosystem was carried out. Six herbicides at three different doses were tried viz., cyhalofop-butyl (80, 160 and 240 ppm), 
cyhalofop-butyl + penoxsulam (150, 300 and 450 ppm), bispyribac-sodium (25, 50 and 75 ppm), fenoxaprop-p-ethyl (60, 12 and 180 ppm), carfentrazone-ethyl (20, 40 and 60 ppm) and chlorimuron-ethyl + metsulfuron-methyl (4, 8 and 12 ppm).

\section{A. Beneficial and pathogenic fungi}

In vitro evaluation of selected herbicides against beneficial fungal microorganism Trichoderma viride (KAU reference culture) and fungal pathogens viz., Rhizoctonia solani and Pyricularia oryzae (KAU reference culture) was carried out by poison food technique [61] at three different doses viz., lower, recommended and higher doses. For this chemicals were mixed separately in $100 \mathrm{ml}$ sterilized PDA media and poured into sterilized petri plates@20 ml/plate and eight mm mycelial discs of pathogens were placed at the center of poisoned media. Plates without herbicide served as control.

\section{B. Beneficial and pathogenic bacteria}

In vitro evaluation of biocontrol agent (Pseudomonas fluorescens), and pathogenic bacteria (Xanthomonas oryzae pv. oryzae) (KAU reference culture) was carried out by filter paper disc method [39]. The solutions of the desired concentrations of the herbicides were prepared separately. Filter paper discs (Whatman No. 42) of 1-2 cm diameter were soaked in the respective chemical solutions for 5 to 10 minutes and transferred onto the centre of the solidified bacterium seeded NA medium (Xanthomonas) and King's B medium (Pseudomonas) in petri plates. The inoculated plates were kept in the refrigerator at $4^{\circ} \mathrm{C}$ for 4 hours to allow diffusion of the chemical into medium. Untreated control plate containing the test bacterium seeded NA and KB inoculated with filter paper disc soaked in distilled water was also maintained. Then the plates were incubated at $28^{\circ} \mathrm{C}$ for 48 hours and observed for the production of inhibition zone around filter paper discs. Factorial Completely Randomized Block Design was adopted with 18 treatments and three replications each.

\section{Observations recorded:}

\section{In vitro evaluation of herbicides against fungal and bacterial (beneficial and pathogenic) microorganisms}

Observations were recorded till the control plate attained full growth of the pathogen. Radial growth (cm) of fungal colonies and per cent inhibition of the pathogen with the herbicide was calculated using the formula given by [57].

$$
\mathrm{C}-\mathrm{T}
$$

$\%$ inhibition of pathogen $=$ $X 100$

C

Where, 
C - Growth of the pathogen in the control

$T$ - Growth of the pathogen in treatment

The statistical software 'WASP 2.0' was used for the analysis [12]. Data on radial growth $(\mathrm{cm})$ and per cent inhibition zone, which showed wide variation were subjected to angular transformation, to make the analysis of variance valid [14] and then analyzed following ANOVA, and the means were compared based on the critical differences (least significant difference) at 0.05 level of significance.

\section{Results}

\section{In vitro evaluation of herbicides on beneficial and pathogenic microorganisms}

The effect of herbicides on disease causing plant pathogens ( $R$. solani, $P$. oryzae and $X$. oryzae pv. oryzae) and microbial bioagents ( $T$. viride and $P$. flourescens) were tested in vitro and the results are presented below.

\section{Effect on pathogens}

\section{Fungi}

Data outlined in Table 1 indicated that increasing concentrations of the different herbicides significantly affected the radial growth and per cent inhibition zone of $R$. solani. Comparing the six herbicides tried, lower radial growth and highest per cent inhibition were observed in bispyribac-sodium $(3.58 \mathrm{~cm}$ and $51.02 \%$ ) over the other herbicidal concentrations. With increasing concentrations of herbicides, radial growth decreased and per cent inhibition zone increased and highest dose recorded radial growth of 4.99 $\mathrm{cm}$ and 38.30 per cent inhibition zone.

Considering the interaction effect of different herbicides and concentrations on $R$. solani, lower radial growth was with higher doses of bispyribac-sodium $(2.43 \mathrm{~cm})$ and fenoxaprop-p-ethyl $(2.93 \mathrm{~cm})$, which were at par with each other. Similarly, highest per cent of inhibition zone was also with bispyribac-sodium (58.70\%) followed by fenoxaprop-p-ethyl (55.21\%) and cyhalofop-butyl + penoxsulam $(54.40 \%)$, whereas all the concentrations of chlorimuron-ethyl + metsulfuron-methyl had no effect on radial growth $(9.00 \mathrm{~cm})$ and per cent inhibition zone (0.29\%) and was at par to control (Fig. 1).

Data shown in Table 1 revealed that different herbicides and their concentrations significantly affected the radial growth and per cent inhibition zone of $P$. oryzae. The lowest radial growth and higher per cent inhibition zone were recorded with cyhalofop-butyl $(1.72 \mathrm{~cm}$ and $62.18 \%)$ along with carfentrazone-ethyl $(1.92 \mathrm{~cm}$ and $60.14 \%)$ and cyhalofop-butyl + penoxsulam $(2.44 \mathrm{~cm}$ and $56.80 \%)$ when compared with control. Comparing the different concentrations of herbicides, lowest radial growth and highest per cent inhibition zone were recorded with higher dose of herbicides $(2.89 \mathrm{~cm}$ and $51.10 \%$ respectively). 
Interaction effect of different herbicides and concentrations on $P$. oryzae revealed that lower radial growth was with higher doses of cyhalofop-butyl $(1.38 \mathrm{~cm})$, carfentrazone-ethyl $(1.48 \mathrm{~cm})$ and cyhalofop-butyl + penoxsulam $(1.53 \mathrm{~cm})$ which were at par with each other. Similarly, highest per cent of inhibition zone was also with cyhalofop-butyl (65.45\%) followed by carfentrazone-ethyl $(64.50 \%)$ and cyhalofop-butyl + penoxsulam (64.05\%), whereas chlorimuron-ethyl + metsulfuron-methyl at all the concentrations had no effect on radial growth $(8.00 \mathrm{~cm})$ and per cent inhibition zone $(0.29 \%)$ as was the case in control (Fig. 2).

\section{Bacteria}

Different herbicides and their concentrations did not significantly affect the radial growth and per cent inhibition zone of $X$. Oryzae pv. oryzae (Table 1 and Fig. 3).

\section{Effect on biocontrol agents}

\section{Fungi}

Different herbicides at increasing concentrations significantly affected the radial growth and per cent inhibition zone of $T$. viride (Table 2). The lowest radial growth was observed with cyhalofop butyl + penoxsulam $(3.95 \mathrm{~cm})$, and highest per cent inhibition zone was recorded in cyhalofop butyl + penoxsulam (48.54\%) which was at par with cyhalofop butyl (44.89\%). Lowest radial growth and highest per cent inhibition zone were recorded with higher dose of herbicides ( $4.75 \mathrm{~cm}$ and $40.84 \%$ respectively).

However, interaction effect of different herbicides and concentrations on $T$. viride showed a different trend. Lowest radial growth and highest per cent of inhibition zone were with higher dose of bispyribacsodium ( $2.98 \mathrm{~cm}$ and $54.85 \%$ ), cyhalofop-butyl + penoxsulam (3.28 cm and $52.84 \%$ ) and cyhalofop-butyl $(3.80 \mathrm{~cm}$ and $49.49 \%)$, which were at par with each other. However, carfentrazone-ethyl at all concentrations and lower concentration of fenoxaprop-p-ethyl had no effect on radial growth $(9.00 \mathrm{~cm})$ and per cent inhibition zone (0.29\%) as was seen in control (Fig. 4).

\section{Bacteria}

Radial growth and per cent inhibition zone of $P$. fluorescens were significantly affected by different herbicides and their concentrations (Table 2). The lowest radial growth and highest per cent inhibition zone were recorded in chlorimuron-ethyl + metsulfuron-methyl $(7.75 \mathrm{~cm}$ and $21.87 \%)$. Lowest radial growth and highest per cent inhibition zone were recorded with higher dose of herbicides $(8.55 \mathrm{~cm}$ and $7.76 \%$ respectively).

In the interaction effect of different herbicides and concentrations on $P$. fluorescens, the lowest radial growth and highest per cent of inhibition zone were recorded with higher doses of chlorimuron-ethyl + metsulfuron-methyl (7.62 cm and 23.0\%) followed by carfentrazone-ethyl (7.70 cm and $22.33 \%)$. Lower and recommended concentrations as well as higher concentration of cyhalofop-butyl, cyhalofop-butyl + penoxsulam, bispyribac-sodium and fenoxaprop-p-ethyl had no effect on radial growth $(9.00 \mathrm{~cm})$ and per cent inhibition zone (0.29\%) (Fig. 5). 


\section{Discussion}

Bispyribac-sodium, fenoxaprop-p-ethyl and cyhalofop-butyl + penoxsulam were highly effective against $R$. solani when applied at all the three doses i.e., higher, recommended and lower doses, and were at par. At recommended doses of application the per cent inhibition zone ranged from 47 to 54 for all herbicides except carfentrazone-ethyl which recorded an inhibition of 17 per cent and chlorimuron-ethyl + metsulfuron-methyl, which did not inhibit the fungus. [41] As per experimental results, indicated that the herbicide mixtures bispyribac-sodium + metamifop and penoxsulam + cyhalofop-butyl had immense suppressive effect on the growth of $R$. solani. Cyhalofop-butyl showed 100 per cent inhibition of $R$. solani at $24 \mathrm{~h}$ incubation, followed by 89 per cent inhibition at $18 \mathrm{~h}$ incubation. However it was ineffective in inhibiting at $5 \mathrm{~min}$ (56.66\%), $30 \mathrm{~min}(0 \%)$ and $6 \mathrm{~h}$ (26.67\%) incubation [48]. A similar study reported retardation in the growth of the pathogen by the herbicides pendimethalin, anilofos, paraquat, butachlor, isoproturon, alachlor and 2,4-D at 25,50, 100 or $500 \mathrm{ppm}$. Paraquat inhibited fungal growth by 99.5 and 78.6 per cent when applied at 500 and $25 \mathrm{ppm}$, respectively. Alachlor at $500 \mathrm{ppm}$ reduced fungal growth by 92.2 per cent [40].

Increased zone of inhibition of $P$. oryzae with higher doses of cyhalofop-butyl (65.45\%), carfentrazoneethyl (64.50\%) and cyhalofop-butyl + penoxsulam (64.05\%) was recorded. At recommended concentrations, the inhibition ranged from 47 to 62 per cent, except in chlorimuron-ethyl + metsulfuronmethyl which did not inhibit fungal growth.Among the different fungicides, highest per cent inhibition of mycelial growth of fungus was recorded in tebuconazole + trifloxystrobin (98.40,99.90 and 99.90\%) and minimum zone of inhibition observed in tricyclazole, with 55.83, 63.62 and $70.52 \%$ at 50,100 and 150 ppm concentration respectively [25]. [30] Recorded highest mycelial inhibition (100\%) at $1000 \mathrm{ppm}$ and least inhibition in chlorothalonil (73.82\%). Similarly, propiconozole, hexaconozole and carbendazim inhibited to the maximum mycelial growth (100\%) and tebuconazole accounted for 100 per cent mycelial growth inhibition at 100 and 200ppm whereas least mycelial growth inhibition was in case of thifluzamide (14.69\%) at 50ppm.

Xanthomonas oryzae pv. oryzae, causing rice bacterial blight, was found to be unaffected by the herbicides tested (Table 2). [7] Showed that the colony width growths of the pathogen recorded after 48 hours of incubation were in the order Blitox-50 + streptocycline (70.25\%), Ergon 44.3 SC (66.4\%), Nativo 75WG (49.91\%) and Mirador (35.33\%).

The inhibition zone of $T$. viride with higher herbicide doses was 54.85 per cent with bispyribac-sodium and 52.84 per cent with cyhalofop-butyl + penoxsulam. At recommended dose it was 45.8 per cent with cyhalofop-butyl and 49.5 per cent with cyhalofop-butyl + penoxsulam. Unlike its effect on plant pathogens, chlorimuron-ethyl + metsulfuron-methyl had a high inhibition zone of 44 per cent, indicating that its application was detrimental to the bioagent $T$. viride. [44] Found that the mycelial growth of the strains T.17 and T.75 was affected by the concentrations of control (OD), recommended dose (1D), and 10 times higher dose of fenoxaprop-p-ethyl derivatives and 2,4-D amine salt. Bispyribac-sodium had no effect on any of the strains tested. [51] Discovered that the herbicides imazethapyr and pendimethalin 
were compatible with soil borne pathogens, allowing them to be used safely alongside antagonist, whereas quizalofop was found to be highly inhibitory to both pathogen and antagonist. [6] Claim that $T$. viride was sensitive to pendimethalin, which caused mycelial growth of $84.66 \mathrm{~mm}$ at a concentration of $0.2 \%$. According to [55] the weedicides diuron and atrazine raised tolerance in the test bioagent from 500 to $2000 \mathrm{~g} / \mathrm{ml}$. Bispyribac-sodium + metamifop, on the other hand, was found to be harmless and safe to antagonistic fungi, T. viride at doses of 60 to $90 \mathrm{~g} / \mathrm{ha}$, which were classified as Class I. (growth inhibition of 8.15 to $22.95 \%$ ). Toxicity levels in the Class II toxicity category (higher dosages of 100 and $110 \mathrm{~g} / \mathrm{ha}$ ) inhibited development by 31.48 and 37.04 per cent, respectively, and were mildly detrimental to the $T$. viride [41].

An inhibition zone of around 25 per cent was observed only at higher doses of chlorimuron-ethyl + metsulfuron-methyl and carfentrazone-ethyl (21.08 and 22.33\%, respectively). [43] Studied the compatibility of bacterial bioagent with herbicides and found that anilofos, showing mean inhibition zone of $0.8 \mathrm{~mm}$, could be considered as compatible with $P$. fluorescens isolate 83, whereas butachlor and pendimethalin showed compatibility with $P$. fluorescens at lower concentrations ( 500 and $250 \mathrm{ppm}$ ) as well as at higher concentrations (2000 and $1000 \mathrm{ppm}$ ) and mean inhibition zone was exhibited only at lower concentrations. This observation was in agreement with the findings of [54] that $P$. fluorescens (PF 43) was highly compatible with 2,4-D sodium salt, metsulfuron methyl + chlorimuron ethyl, cyhalofopbutyl, pyrazosulfuron ethyl, pretilachlor, penoxsulam and bispyribac-sodium. [41] Found that that bispyribac-sodium + metamifop at different tested concentrations viz., 100, 120, 140, 160, 180, 200 and $220 \mu \mathrm{L} / \mathrm{L}$ (corresponding to the field doses of 50,60,70, 80, 90, 100 and $120 \mathrm{~g} / \mathrm{ha}$ ) did not exert any inhibition on the growth of $P$. fluorescens. [17], documenting experimental results pertaining to compatibility of $P$. fluorescens with herbicides, found that the strain $P$. fluorescens was compatible with all the tested herbicides viz., quizalofop ethyl, pyrithiobac sodium, oxyflourfen, cyhalofop-butyl, glyphosate + ammonium sulphate, pendimethalin, 2,4-D sodium salt, imazethapyr, atrazine and glyphosate at all the three concentrations (100, 500 and 1000 ppm) tested.

Most of the commonly used herbicides at recommended doses had inhibitory effects on growth of plant pathogens $R$. solani and $P$. oryzae. However, beneficial bioagent $T$. viride was also inhibited. Herbicides used in combination could have an additive effect and result in enhanced disease control compared to their individual application. The judicious selection and use of herbicides is warranted to obtain disease control in addition to weed control. The possibility of their utilization in integrated disease management needs to be investigated.

In vitro evaluation of herbicides revealed that bispyribac-sodium and cyhalofop-butyl + penoxsulam had greatest inhibitory effect on pathogenic microorganisms Rhizoctonia solani and Pyricularia oryzae, but showed no effect on Xanthomonas oryzaepv. oryzae, and were less harmful to biocontrol agents Trichoderma viride and Pseudomonas fluorescens at recommended doses.

\section{References}


1. Abdel, G. Interactions between dinitroanalines herbicides and some fungi causing sheath blight disease in cucurbits. Arab Univ. J. Agric. Sci. 10(1), $375 \otimes 390$ (2002).

2. Agrios, G. N. Plant Pathology (5th edition). Elsevier Academic Press, San Diego, CA, 922p (2005).

3. Altman, J. Herbicide-pathogen interaction in plant disease. Pesticide Outlook, 2(1): 17 \21 (1991).

4. Altman, J. \& Campbell, C. L. The influence of herbicides on plant diseases. Ann. Rev. Phytopathol. 15, 361 \ 386 (1977).

5. Altman, J. \& Campbell, C. L. Herbicides and environment: a review on stimulating and inhibiting interactions with plant diseases. Z. Pflanzenkrankheiten Pflanzenschutz, 86, $290 \otimes 302$ (1979).

6. Aswathi, S., Gade, R. M. \& Shitole, A. V. Studies on tolerance and sensitivity of fungal and bacterial bioagent to three pesticides commonly used in agriculture. IPS (New Delhi), 14th International Workshop on Trichoderma and Gliocladium, Nagpur.133p (2016).

7. Bala, A., Rai, B., Priya, S. \& Kumar, R. In vitro evaluation of various fungicides and plant extracts against Xanthomonas oryazae pv. oryzae isolated from rice (Oryza sativa L.). Int. J. Current Microbiol. Appl. Sci. 6(5), $421 \otimes 427$ (2017).

8. Brown, L. M. et al. Pesticide exposures and other agricultural risk factors for leukemia among men in lowa and Minnesota. Cancer Res. 50, 6585 \& 6591 (1990).

9. Chahal S. S, Sokhi, S. S. \& Ratan G. S. Investigation on sheath blight of rice in Punjab. Indian Phytopathol. 56, $22 \otimes 26$ (2003).

10. Chaudhary, B., Rampur, P. B. \& Lal, K. K. Neck blast-resistant lines of Radha-17 isolated. IRRN (Philippines), 19(1), 11 (1994).

11. Ciraj, M. Impact of some sulfonylurea herbicides upon selected soil fungi. Sodobnok metijstvo, 29, 99 $\otimes 108$ (1996).

12. Freed, R. MSTAT version 4.0. Department of Crop and Soil Sciences. Michigan State University (1986).

13. Gilbert, M. J., Soanes, D. M. \& Talbot, N. J. Functional genomic analysis of the rice blast fungus Magnaporthe grisea. Appl. Mycol. Biotechnol. 4, 331 \ 352 (2004).

14. Gomez, A. K. \& Gomez, A. A. Statistical Procedures for Agricultural Research (2nd ed.). John Wiley and Sons, New York, 657p (1984).

15. Greer, C. A., Scardaci, S. C. \& Webster, R. K. First report of Rice Blast caused by Magnaporthe grisea in California. Plant Disease, 81(9), 1094 (1997).

16. Gupta, V. Compatibility of biocontrol agent Trichoderma harzianum with pesticides. J. Mycol. Plant Pathol. 34, $504 \otimes 505$ (2004).

17. Hanuman, L. N. \& Madhavi, G. B. Compatibility of Pseudomonas fluorescens with pesticides in vitro. Int. J. Current Microbiol. Appl. Sci. 7(3), 3310 \3315 (2018).

18. Hollier, C. A., Groth, D. E., Rush, M. C. \& Webster, R. K. Common names of plant diseases. The American Phytopathological Society, St. Paul, MN (1993). 
19. Hung, J., Jiquan, B.L., Zhao, S. Y. \& Li, S. Isolation characterization of a strain capable of degrading imazthapyr and its use in degradation of the herbicides in soil. Current Microbiol. 59, $363 \rrbracket 367$ (2009).

20. Jabeen, R., Ashraf, M., Ahmad, I. \& Iftikhar, T. Purification and bioassays of bioactive fraction from Curcuma longa against Xanthomonas oryzae pv. oryzae causing BLB disease in rice. Pakistan J. Bot 43(2), 1335 \1342 (2011a).

21. Jabeen, R., Iftikhar, T., Ashraf, M. \& Ahmad, I. Virulence/aggressiveness testing of Xanthomonas oryzae pv. oryzae isolates causes BLB disease in rice cultivars of Pakistan. Pak. J. Bot. 43(3), 1725 《 1728 (2011b).

22. Jabeen, R., Iftikhar, T. \& Batool, H. Isolation, characterization, preservation and pathogenicity test of Xanthomonas oryzae pv. oryzae causing BLB disease in rice. Pak. J. Bot. 44(1), $261 \rrbracket 265$ (2012).

23. Katan, J. \& Eshel, Y. Interactions between herbicides and plant pathogens. Residue Rev. 45, $145 \otimes 147$ (1973).

24. KAU. Package of Practices Recommendations: Crops 2016 (15th ed.). Kerala Agricultural University, Thrissur. 392p (2016).

25. Kulmitra, A. K., Sanath Kumar, V. B., Thejesha, A. G., Ghosh, A. \& Sahu, P. In vitro evaluation of fungicides against Pyricularia oryzae (Cav.) causing rice blast disease. Int. J. Chem. Stud. 5(4), 506 区 509 (2017).

26. Lee, F. N. \& Rush, M. C. (1983). Rice sheath blight: a major rice disease. Plant Disease, 67, $829 \square 832$.

27. Levesque, A. C. \& Rahe, J. E. Herbicide interactions with fungal root pathogens, with special reference to glyphosate. Ann. Rev. Phytopathol. 30, 579 \602 (1992).

28. Madhuri, V. \& Reddy, N. Compatibility of herbicides with fungicides against Sclerotium rolfsii, Rhizoctonia solani, and Fusarium udum. Bioinfolet, 10, 1032 \ 1036 (2013).

29. Madhuri, V., Arunodhayam, K. \& Reddy, N. P. E. A review on target effect of herbicides and compatibility of herbicides with fungicides on soil borne pathogens- Sclerotium rolfsii Sacc., Rhizoctonia solani Kuhn. And Fusarium udum Butler. Current Biotica, 7, $105 \otimes 123$ (2013).

30. Mallikarjuna, B., Nagaraj, M. S. \& Palanna, K. B. In vitro evaluation of fungicides against blast of foxtail millet caused by Pyricularia setariae. Int. J. Current Microbiol. Appl. Sci. 9(2), 2364区 2374 (2020).

31. Mehrotra, R. S. Plant Pathology. Tata MC Graw-Hill Co. Ltd., New Delhi (1998).

32. Mew, T. W. Current status and future prospects of research on bacterial blight of rice. Ann. Rev. Phytopathol. 25, $359 \llbracket 382$ (1987).

33. Mew, T. W. \& Gonzales, P. A Handbook of Rice Seed borne Fungi. International Rice Research Institute, Los Banos, Philippines, 83p (2002).

34. Milicic, B., Terzic, V. A. \& Kuzmanovic, D. Examination of capability of some soil microorganisms of inactivating simazine and atrazine. Zemljiste-i-biljka (Serbia and Montenegro). Acta Biologica Yugoslavica, 52, $35 \rrbracket 44$ (2003). 
35. O'Sullivan D.J. \& O'Gara, F. Traits of fluorescent Pseudomonas spp. involved in suppression of plant root pathogens. Microbiol. Rev. 56, 662-676 (1992).

36. Ou, S.H. Rice diseases (2nd Ed). Commonwealth mycological institute. Kew, Surrey, England. $61 \otimes 96$ (1985).

37. Ouazzani, T. A., Mouria, A., Douira, A., Benkirane, R., Mlaiki, A. \& El-Yachioui, M. In vitro effect of pH and temperature on the ability of Trichoderma spp., to reduce the growth of Pyricularia oryzae. J. CAB Direct, 96, 19-24 (1998).

38. Papavizas, G. C. Trichoderma and Gliocladium- Their biology, ecology and potential of biocontrol. Ann. Rev. Phytopathol. 23, 23-54 (1983).

39. Pauli, A. \& Schilcher, H. In vitro antimicrobial activities of essential oils monographed in the European Pharmacopoeia. In: Baser, C. K. H. \& Buchbauer, G. (eds). Handbook of Essential Oils. Science, Technology and Application (6th Ed). New York, NY: CRC Press. Taylor \& Francis Group, 353-548 (2010).

40. Rai, J. P., Dubey, K. S. \& Kumar, B. In vitro screening of different fungicides and antifungal antibiotics against Rhizoctonia solani causing aerial blight of soybean. J. Plant Disease Sci. 2(1) 54-56 (2007).

41. Raj, S. K., Syriac, E. K., Anith, K. N. \& Meenakumari, K. S. Compatibility of biocontrol agents and N fixing organisms with post-emergence pre-mix herbicide-bispyribac-sodium + metamifop $14 \% \mathrm{SE}$. J. Appl. Natutal Sci. 9(3), 1510-1514 (2017).

42. Rao, C. V. R. \& Divakar, B. J. Effect of three pesticides on the fungal bioagent, Trichoderma viride. Front Microbial Biotechnol. Plant Pathol. 24 183-186 (2002).

43. Reddy, K. R. N., Choudary, K. A. \& Reddy, M. S. Antifungal metabolites of Pseudomonas fluorescens isolated from rhizosphere of rice crop. J. Mycol. Plant Pathol. 37(2) (2007).

44. Reyes, Y., Infante, D., Garcia-Borrego, J., Pozo, E. D., Cruz, A. \& Martinez, B. Compatibilidad de Trichoderma asperellum Samuels con herbicidas de mayor uso en el cultivo del arroz. Rev. Proteccion Vegetables, 27(1), 45-53 (2012).

45. Robert, R. S. Research priorities for rice biotechnology. In: Rice Biotechnology: Toenniessen. (Eds.), Alden press Ltd., London. 35-37 (1991).

46. Rush, M. C. \& Lee, F. N. Sheath blight. In: Compendium of Rice Diseases. Webster, R.K., and Gunnell, P.S., (eds). The American Phytopathology Society, St. Paul, MN. 22-23 (1992).

47. Salim, M., Akram, M., Akhtar, M. \& Ashraf, M. Rice-A production hand book. Pakistan Agricultural Research Council, 70p (2003).

48. Sandhya, Y., Rajan, C. P. D., Kumar, M. R. \& Rani, A. R. Screening of herbicides against sclerotial viability of the Rhizoctonia solani in vitro and in soil. Int. J. Current Microbiol. Appl. Sci. 7(7), 129012972018.

49. Scardaci, S. C. et al. Rice blast: A new disease in California. Agronomy Fact Sheet Series. Departement of Agronomy and Range Science, University of California, Davis. http://agronomy.ucdavis.edu/uccerice/AFS/agfs0297.html. (1997). 
50. Sharma, O. P. \& Bambawale, O. M. Integrated management of key diseases of cotton and rice. Integrated Manag. Plant Pest Diseases, 4, 271-302 (2008).

51. Sharma, L. Studies on compatibility of Trichoderma viride with recommended fungicides, insecticides, herbicides and plant products against major soil borne pathogen. M.Sc. Thesis (Unpublished). Jawaharlal Nehru KrishiVishwaVidyalaya (2015).

52. Singh H. B. Trichoderna: A boon for biopesticide industry. Indian J. Mycol. Plant Pathol. 36(3), 373384 (2007).

53. Srivastava, D. N. Epidemiology and control of bacterial blight of rice in India. Proceedings of rice diseases and their control by growing resistant varieties and other measures. Agric. Fores. Fisheries Res. Council, 11-18 (1967).

54. Surendran, M., Kannan G. S., Kamala, N. \& Leenakumary, S. Compatibility of Pseudomonas fluorescens with agricultural chemicals. J. Biol. Control, 26(2), 190-193 (2012).

55. Sushir, M. A., Sawashe, S. G. \& Sali, V. M. Induction of higher tolerance in Trichoderma harzianum Rifai against selective pesticides in vitro. IPS (New Delhi), 14th International Workshop on Trichoderma and Gliocladium, Nagpur, 131p (2016).

56. Swings, J., Mooter, M., Vauterin, V.D., Hoste, L., Gillis, B., Mew, T.W. \& Kersters, K. Reclassification of the causal agents of bacterial blight (Xanthomonas campestris pv. oryzae) and bacterial leaf streak (Xanthornonas campestris pv. oryzicola) of rice as pathovars of Xanthomonas oryzae (ex Ishiyama 1922) sp. nov. nom. rev. Int. J. Systemic Microbiol. 40 309-311 (1990).

57. Vincent, J. M. Distortion of fungal hyphae in the presence of certain inhibitors. Nature, 159: 850 (1927).

58. Wasi, S., Jeelani, G. \& Ahmad, M. Biochemical characterization of a multiple heavy metal, pesticides and phenol resistant Pseudomonas fluorescens strain. Water, Air and Soil Polloution, 220, 89-99 (2007).

59. Webster, R. K. \& Gunnell, P. S. Compendium of Rice Diseases. The American Phytopathological Society, St. Paul, MN, 86p (1992).

60. Yu. S. M., Templeton, G. E. \& Wolf, D. C. Trifluralin concentration and the growth of Fusarium solani $f$. sp. Cucurvitae in liquid medium and soil. Soil Biol. Biochem. 20, 607-612 (1988).

61. Zentmyer, G. A. The world of Phytophthora. In: Erwin, D. C., Bartnicki-Garcia, S. and Tsao, P. H. (eds), Phytophthora: Its Biology, Taxonomy, Ecology and Pathology, American Phytopathological Society, St Paul, Minnesota, USA, pp. 1-8. (1955).

62. Zou, J. H. et al. Mapping quantitative trait loci controlling sheath blight resistance in two rice cultivars (Oryza sativa L.). Theoritical Appli. Genetics, 101, 569-573 (2000).

\section{Tables}

Table 1 Effect of herbicides on radial growth and \% inhibition zone on fungal and bacterial pathogens 


\begin{tabular}{|c|c|c|c|c|c|c|c|}
\hline \multirow{2}{*}{\multicolumn{2}{|c|}{ Treatments }} & \multicolumn{2}{|c|}{ R. solani } & \multicolumn{2}{|c|}{ P. oryzae } & \multicolumn{2}{|c|}{ X. oryzaepv.oryzae } \\
\hline & & $\begin{array}{l}\text { Radial } \\
\text { growth } \\
\text { (cm) }\end{array}$ & $\begin{array}{l}\% \\
\text { inhibition } \\
\text { zone }\end{array}$ & $\begin{array}{l}\text { Radial } \\
\text { growth } \\
(\mathrm{cm})\end{array}$ & $\begin{array}{l}\% \\
\text { inhibition } \\
\text { zone }\end{array}$ & $\begin{array}{l}\text { Radial } \\
\text { growth } \\
\text { (cm) }\end{array}$ & $\begin{array}{l}\% \\
\text { inhibition } \\
\text { zone }\end{array}$ \\
\hline \multicolumn{8}{|l|}{ Factor A (Herbicide) } \\
\hline \multicolumn{2}{|l|}{ Cyhalofop-butyl } & 3.77 & 49.66 & 1.76 & 62.18 & 9.00 & 0.29 \\
\hline \multicolumn{2}{|l|}{$\begin{array}{l}\text { (Cyhalofop-butyl + } \\
\text { penoxsulam) }\end{array}$} & 3.69 & 50.23 & 1.92 & 60.74 & 9.00 & 0.29 \\
\hline \multicolumn{2}{|l|}{ Bispyribac-sodium } & 3.58 & 51.02 & 3.42 & 49.28 & 9.00 & 0.29 \\
\hline \multicolumn{2}{|l|}{ Fenoxaprop-p-ethyl } & 3.89 & 48.94 & 3.61 & 47.87 & 9.00 & 0.29 \\
\hline \multicolumn{2}{|l|}{ Carfentrazone-ethyl } & 8.41 & 10.55 & 2.44 & 56.80 & 9.00 & 0.29 \\
\hline \multicolumn{2}{|l|}{$\begin{array}{l}\text { (Chlorimuron-ethyl + } \\
\text { metsulfuron-methyl) }\end{array}$} & 9.00 & 0.29 & 8.00 & 0.29 & 9.00 & 0.29 \\
\hline \multicolumn{2}{|l|}{ SEm } & 1.05 & 9.49 & 0.95 & 9.49 & 0.00 & 0.00 \\
\hline \multicolumn{2}{|l|}{$C D(P<0.05)$} & 0.31 & 3.79 & 0.10 & 0.80 & NS & NS \\
\hline \multicolumn{8}{|c|}{ Factor B (Concentration) } \\
\hline \multicolumn{2}{|l|}{ Lower dose (LD) } & 5.96 & 30.32 & 3.98 & 42.68 & 9.00 & 0.29 \\
\hline \multicolumn{2}{|c|}{ Recommended dose (RD) } & 5.22 & 36.72 & 3.70 & 44.80 & 9.00 & 0.29 \\
\hline \multicolumn{2}{|l|}{ Higher dose (HD) } & 4.99 & 38.30 & 2.89 & 51.10 & 9.00 & 0.29 \\
\hline \multicolumn{2}{|l|}{ SEm } & 0.29 & 2.44 & 0.33 & 2.53 & 0.00 & 0.00 \\
\hline \multicolumn{2}{|l|}{$C D(p<0.05)$} & 0.22 & 2.68 & 0.07 & 0.57 & NS & NS \\
\hline \multicolumn{8}{|c|}{ Herbicide $x$ concentration $(A \times B)$} \\
\hline \multirow[t]{3}{*}{ Cyhalofo-butyl } & $\begin{array}{l}\text { LD @ } \\
80 \\
\text { ppm }\end{array}$ & 4.05 & 47.87 & 2.20 & 58.38 & 9.00 & 0.29 \\
\hline & $\begin{array}{l}\text { RD @ } \\
160 \\
\text { ppm }\end{array}$ & 3.65 & 50.44 & 1.68 & 62.72 & 9.00 & 0.29 \\
\hline & $\begin{array}{l}\mathrm{HD} @ \\
240 \\
\mathrm{ppm}\end{array}$ & 3.62 & 50.66 & 1.38 & 65.45 & 9.00 & 0.29 \\
\hline \multirow[t]{2}{*}{$\begin{array}{l}\text { (Cyhalofop-butyl + } \\
\text { penoxsulam) }\end{array}$} & $\begin{array}{l}\text { LD @ } \\
150 \\
\text { ppm }\end{array}$ & 4.40 & 45.64 & 2.37 & 57.06 & 9.00 & 0.29 \\
\hline & $\begin{array}{l}\text { RD @ } \\
300\end{array}$ & 3.05 & 54.40 & 1.87 & 61.12 & 9.00 & 0.29 \\
\hline
\end{tabular}




\begin{tabular}{|c|c|c|c|c|c|c|c|}
\hline & \multicolumn{7}{|l|}{ ppm } \\
\hline & $\begin{array}{l}\mathrm{HD} @ \\
450 \\
\mathrm{ppm}\end{array}$ & 3.62 & 50.66 & 1.53 & 64.05 & 9.00 & 0.29 \\
\hline \multirow[t]{3}{*}{ Bispyribac-sodium } & $\begin{array}{l}\text { LD @ } \\
25 \\
\text { ppm }\end{array}$ & 4.25 & 46.59 & 4.38 & 42.25 & 9.00 & 0.29 \\
\hline & $\begin{array}{l}\mathrm{RD} @ \\
50 \\
\mathrm{ppm}\end{array}$ & 4.07 & 47.76 & 3.43 & 49.07 & 9.00 & 0.29 \\
\hline & $\begin{array}{l}\mathrm{HD} @ \\
75 \\
\mathrm{ppm}\end{array}$ & 2.43 & 58.70 & 2.43 & 56.53 & 9.00 & 0.29 \\
\hline \multirow[t]{3}{*}{ Fenoxaprop-p-ethyl } & $\begin{array}{l}\text { LD @ } \\
60 \\
\text { ppm }\end{array}$ & 5.08 & 41.27 & 4.55 & 41.05 & 9.00 & 0.29 \\
\hline & $\begin{array}{l}\mathrm{RD} @ \\
120 \\
\mathrm{ppm}\end{array}$ & 3.67 & 50.35 & 3.75 & 46.80 & 9.00 & 0.29 \\
\hline & $\begin{array}{l}\text { HD @ } \\
180 \\
\text { ppm }\end{array}$ & 2.93 & 55.21 & 2.53 & 55.76 & 9.00 & 0.29 \\
\hline \multirow[t]{3}{*}{$\begin{array}{l}\text { Carfentrazone- } \\
\text { ethyl }\end{array}$} & $\begin{array}{l}\text { LD @ } \\
20 \\
\text { ppm }\end{array}$ & 9.00 & 0.29 & 2.37 & 57.05 & 9.00 & 0.29 \\
\hline & $\begin{array}{l}\mathrm{RD} @ \\
40 \\
\mathrm{ppm}\end{array}$ & 7.88 & 17.07 & 3.47 & 48.83 & 9.00 & 0.29 \\
\hline & $\begin{array}{l}\mathrm{HD} @ \\
60 \\
\mathrm{ppm}\end{array}$ & 8.35 & 14.29 & 1.48 & 64.50 & 9.00 & 0.29 \\
\hline \multirow[t]{3}{*}{$\begin{array}{l}\text { (Chlorimuron-ethyl } \\
+ \text { metsulfuron- } \\
\text { methyl) }\end{array}$} & $\begin{array}{l}\text { LD @ } \\
4 \\
\text { ppm }\end{array}$ & 9.00 & 0.29 & 8.00 & 0.29 & 9.00 & 0.29 \\
\hline & $\begin{array}{l}\mathrm{RD} @ \\
8 \\
\mathrm{ppm}\end{array}$ & 9.00 & 0.29 & 8.00 & 0.29 & 9.00 & 0.29 \\
\hline & $\begin{array}{l}\mathrm{HD} @ \\
12 \\
\mathrm{ppm}\end{array}$ & 9.00 & 0.29 & 8.00 & 0.29 & 9.00 & 0.29 \\
\hline$C D(p<0.05)$ & & 0.53 & 6.56 & 0.17 & 1.39 & NS & NS \\
\hline
\end{tabular}

Table 2 Effect of herbicides on radial growth and \% inhibition zone on fungal and bacterial biocontrol agents 


\begin{tabular}{|c|c|c|c|c|c|}
\hline \multirow{2}{*}{\multicolumn{2}{|c|}{ Treatments }} & \multicolumn{2}{|l|}{ T. viride } & \multicolumn{2}{|l|}{ P. fluorescens } \\
\hline & & $\begin{array}{l}\text { Radial } \\
\text { growth (cm) }\end{array}$ & $\begin{array}{l}\% \\
\text { inhibition } \\
\text { zone }\end{array}$ & $\begin{array}{l}\text { Radial } \\
\text { growth (cm) }\end{array}$ & $\begin{array}{l}\% \\
\text { inhibition } \\
\text { zone }\end{array}$ \\
\hline \multicolumn{6}{|l|}{ Factor A (Herbicide) } \\
\hline \multicolumn{2}{|l|}{ Cyhalofop-butyl } & 4.52 & 44.89 & 9.00 & 0.29 \\
\hline \multicolumn{2}{|c|}{ (Cyhalofop-butyl + penoxsulam) } & 3.95 & 48.54 & 9.00 & 0.29 \\
\hline \multicolumn{2}{|l|}{ Bispyribac-sodium } & 5.42 & 38.49 & 9.00 & 0.29 \\
\hline \multicolumn{2}{|l|}{ Fenoxaprop-p-ethyl } & 7.76 & 14.96 & 9.00 & 0.29 \\
\hline \multicolumn{2}{|l|}{ Carfentrazone-ethyl } & 9.00 & 0.29 & 7.78 & 21.62 \\
\hline \multicolumn{2}{|c|}{$\begin{array}{l}\text { (Chlorimuron-ethyl + metsulfuron- } \\
\text { methyl) }\end{array}$} & 5.32 & 39.24 & 7.75 & 21.87 \\
\hline \multicolumn{2}{|l|}{ SEm } & 0.80 & 7.80 & 0.26 & 4.38 \\
\hline \multicolumn{2}{|l|}{$C D(P<0.05)$} & 0.41 & 3.73 & 0.03 & 0.27 \\
\hline \multicolumn{6}{|l|}{ Factor B (Concentration) } \\
\hline \multicolumn{2}{|l|}{ Lower dose (LD) } & 6.92 & 23.97 & 8.62 & 7.17 \\
\hline \multicolumn{2}{|l|}{ Recommended dose (RD) } & 6.33 & 28.39 & 8.59 & 7.38 \\
\hline \multicolumn{2}{|l|}{ Higher dose (HD) } & 4.74 & 40.84 & 8.55 & 7.76 \\
\hline \multicolumn{2}{|l|}{ SEm } & 0.65 & 5.05 & 0.02 & 1.28 \\
\hline \multicolumn{2}{|l|}{$C D(p<0.05)$} & 0.29 & 2.64 & 0.02 & 0.19 \\
\hline \multicolumn{6}{|c|}{ Herbicide $x$ concentration $(A \times B)$} \\
\hline \multirow[t]{3}{*}{ Cyhalofo-butyl } & $\begin{array}{l}\text { LD @ } 80 \\
\text { ppm }\end{array}$ & 5.38 & 39.34 & 9.00 & 0.29 \\
\hline & $\begin{array}{l}\text { RD @ } \\
160 \text { ppm }\end{array}$ & 4.37 & 45.85 & 9.00 & 0.29 \\
\hline & $\begin{array}{l}\mathrm{HD} @ \\
240 \mathrm{ppm}\end{array}$ & 3.80 & 49.49 & 9.00 & 0.29 \\
\hline \multirow[t]{3}{*}{$\begin{array}{l}\text { (Cyhalofop-butyl + } \\
\text { penoxsulam) }\end{array}$} & $\begin{array}{l}\text { LD @ } \\
150 \text { ppm }\end{array}$ & 4.78 & 43.19 & 9.00 & 0.29 \\
\hline & $\begin{array}{l}\text { RD @ } \\
300 \mathrm{ppm}\end{array}$ & 3.78 & 49.58 & 9.00 & 0.29 \\
\hline & $\begin{array}{l}\mathrm{HD} @ \\
450 \mathrm{ppm}\end{array}$ & 3.28 & 52.84 & 9.00 & 0.29 \\
\hline Bispyribac-sodium & LD@ @25 & 6.07 & 34.81 & 9.00 & 0.29 \\
\hline
\end{tabular}




\begin{tabular}{|c|c|c|c|c|c|}
\hline & \multicolumn{5}{|l|}{ ppm } \\
\hline & $\begin{array}{l}\mathrm{RD} @ 50 \\
\mathrm{ppm}\end{array}$ & 7.22 & 25.81 & 9.00 & 0.29 \\
\hline & $\begin{array}{l}\mathrm{HD} @ 75 \\
\mathrm{ppm}\end{array}$ & 2.98 & 54.85 & 9.00 & 0.29 \\
\hline \multirow[t]{3}{*}{ Fenoxaprop-p-ethyl } & $\begin{array}{l}\text { LD @ } 60 \\
\text { ppm }\end{array}$ & 9.00 & 0.29 & 9.00 & 0.29 \\
\hline & $\begin{array}{l}\text { RD @ } \\
120 \mathrm{ppm}\end{array}$ & 8.67 & 6.68 & 9.00 & 0.29 \\
\hline & $\begin{array}{l}\text { HD @ } \\
180 \mathrm{ppm}\end{array}$ & 5.60 & 37.90 & 9.00 & 0.29 \\
\hline \multirow[t]{3}{*}{ Carfentrazone-ethyl } & $\begin{array}{l}\text { LD @ } 20 \\
\text { ppm }\end{array}$ & 9.00 & 0.29 & 7.85 & 20.95 \\
\hline & $\begin{array}{l}\mathrm{RD} @ 40 \\
\mathrm{ppm}\end{array}$ & 9.00 & 0.29 & 7.78 & 21.57 \\
\hline & $\begin{array}{l}\mathrm{HD} @ 60 \\
\mathrm{ppm}\end{array}$ & 9.00 & 0.29 & 7.70 & 22.33 \\
\hline \multirow[t]{3}{*}{$\begin{array}{l}\text { (Chlorimuron-ethyl + } \\
\text { metsulfuron-methyl) }\end{array}$} & $\begin{array}{l}\text { LD @ } 4 \\
\text { ppm }\end{array}$ & 7.27 & 25.91 & 7.85 & 20.95 \\
\hline & $\begin{array}{l}\mathrm{RD} @ 8 \\
\mathrm{ppm}\end{array}$ & 4.93 & 42.12 & 7.78 & 21.57 \\
\hline & $\begin{array}{l}\mathrm{HD} @ 12 \\
\mathrm{ppm}\end{array}$ & 3.77 & 49.70 & 7.62 & 23.08 \\
\hline$C D(p<0.05)$ & & 0.72 & 6.46 & 0.27 & 0.14 \\
\hline
\end{tabular}

Figures 

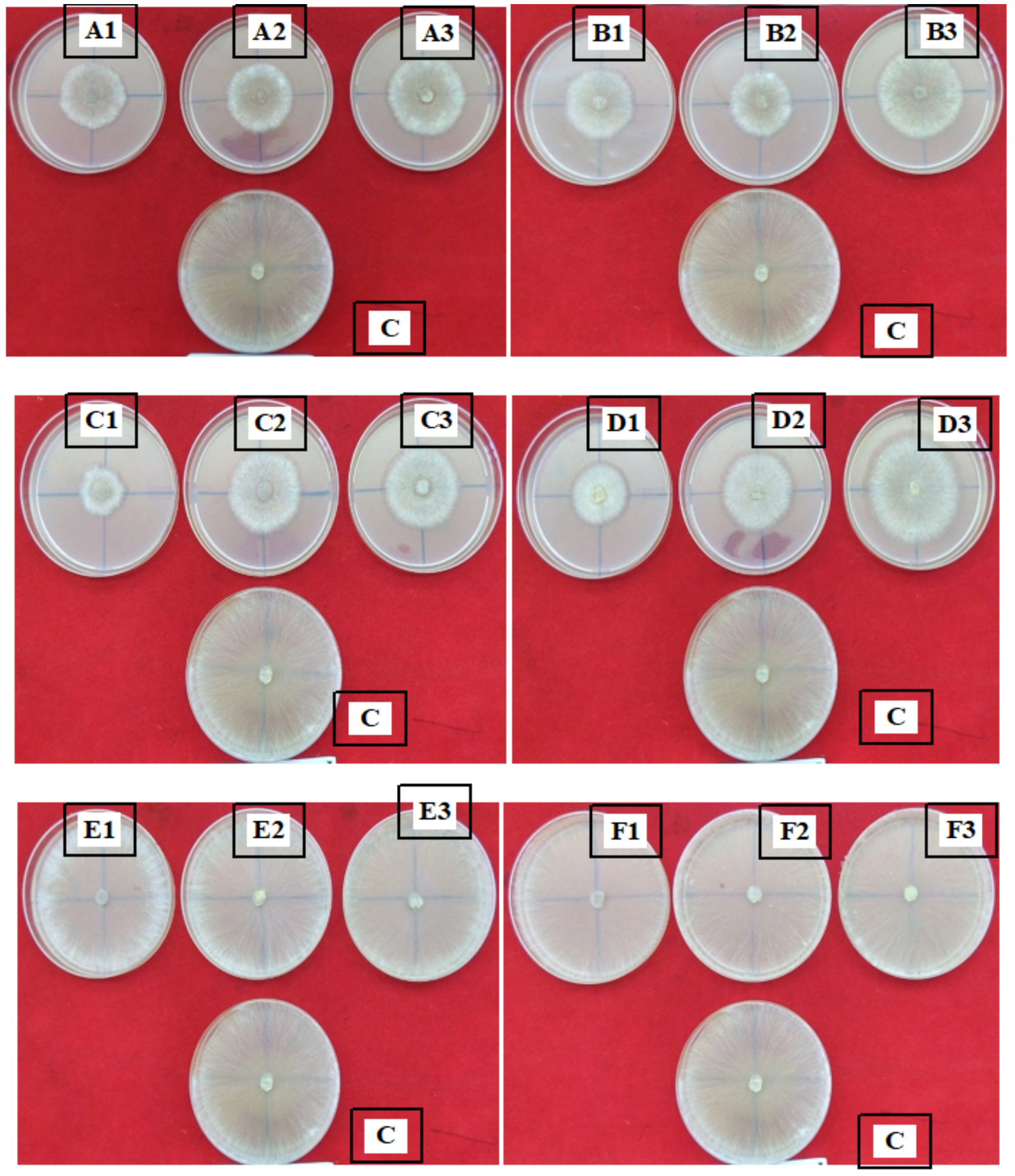

\section{Figure 1}

\section{In vitro evaluation of herbicides against Rhizoctonia solani}

A1: Cyhalofop-butyl (240 ppm); A2 (160 ppm); A3 (80 ppm); B1: (Cyhalofop-butyl + penoxsulam) (450 ppm); B2: (300 ppm); B3: (150 ppm); C1: Bispyribac-sodium (75 ppm); C2: (50 ppm); C3: (25 ppm); D1: Fenoxaprop-p-ethyl (180 ppm); D2: (120 ppm); D3 (60 ppm); E1: Carfentrazone-ethyl (60 ppm); E2: (40 
ppm); E3: (20 ppm); F1: (Chlorimuron-ethyl + metsulfuron-methyl) (8 ppm); F2: (4 ppm); F3: (2 ppm); C: Control plate
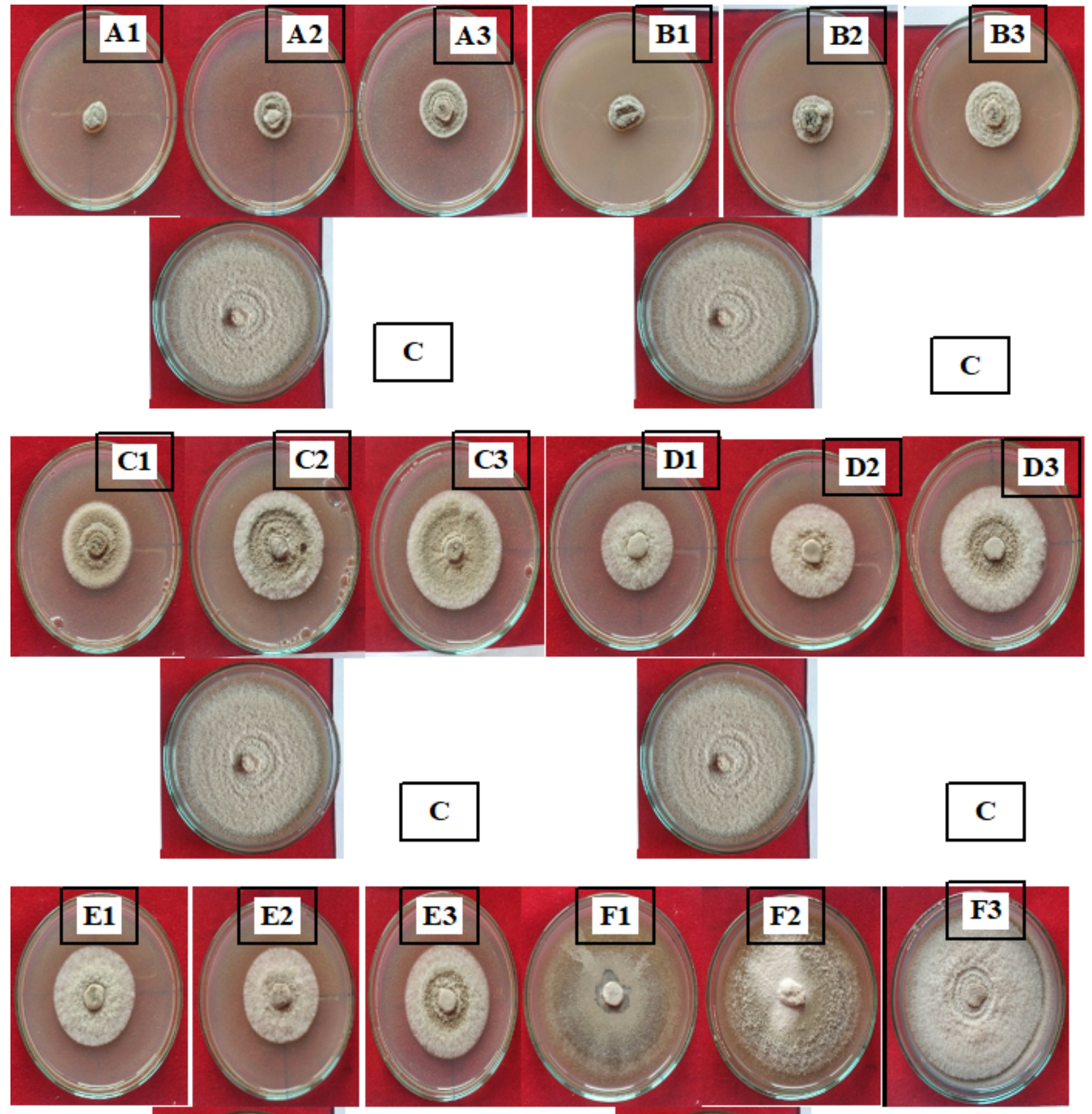

\section{C}

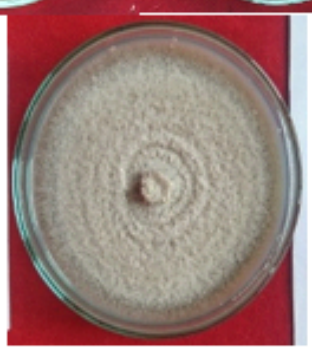

C

Figure 2 


\section{In vitro evaluation of herbicides against Pyricularia oryzae}

A1: Cyhalofop-butyl (240 ppm); A2 (160 ppm); A3 (80 ppm); B1: (Cyhalofop-butyl + penoxsulam) (450 ppm); B2: (300 ppm); B3: (150 ppm); C1: Bispyribac-sodium (75 ppm); C2: (50 ppm); C3: (25 ppm); D1: Fenoxaprop-p-ethyl (180 ppm); D2: (120 ppm); D3 (60 ppm); E1: Carfentrazone-ethyl (60 ppm); E2: (40 ppm); E3: (20 ppm); F1: (Chlorimuron-ethyl + metsulfuron-methyl) (8 ppm); F2: (4 ppm); F3: (2 ppm); C: Control plate
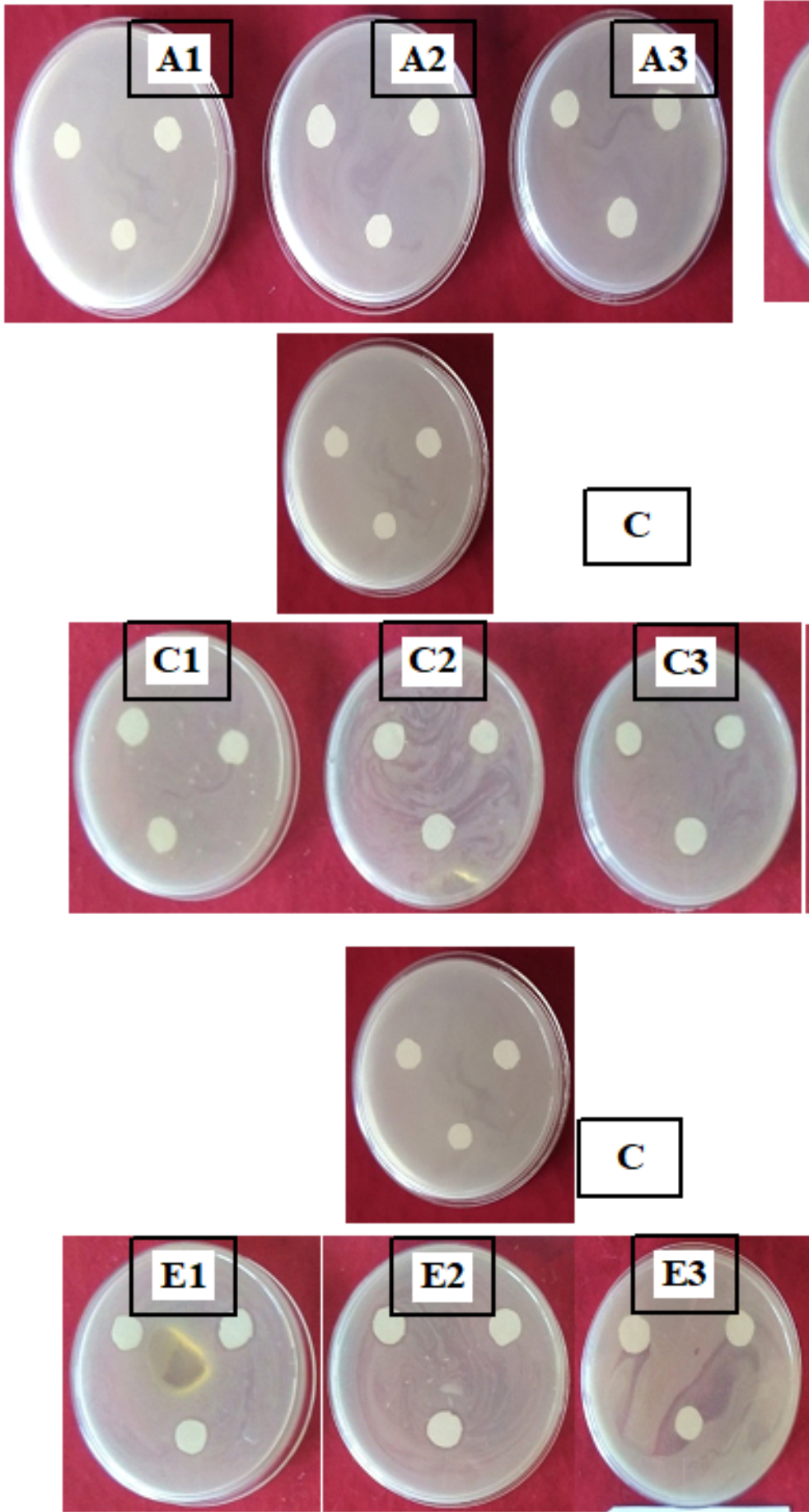
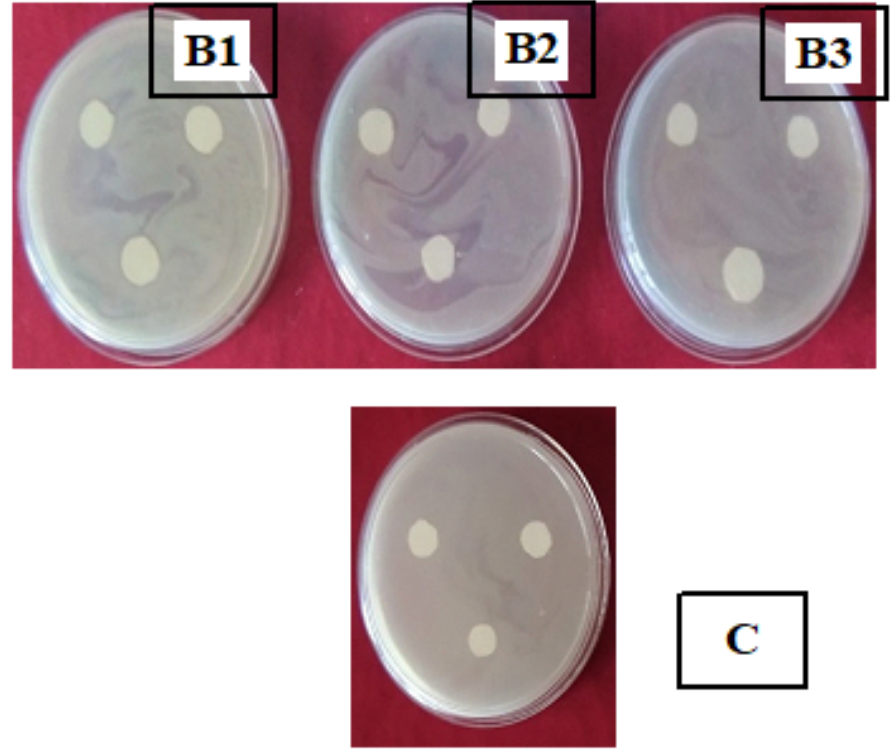

C
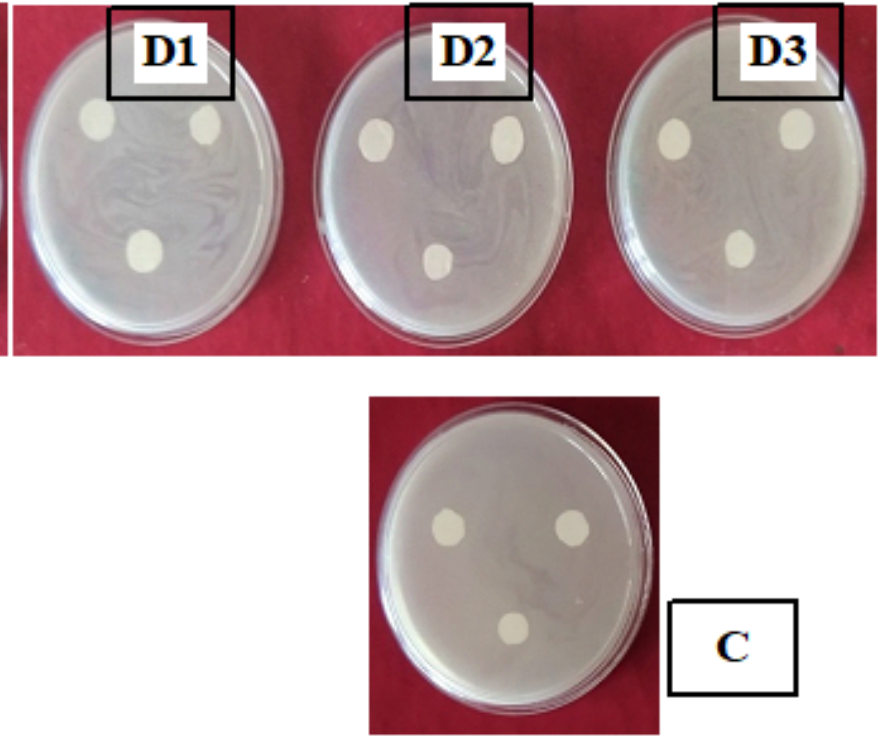

C

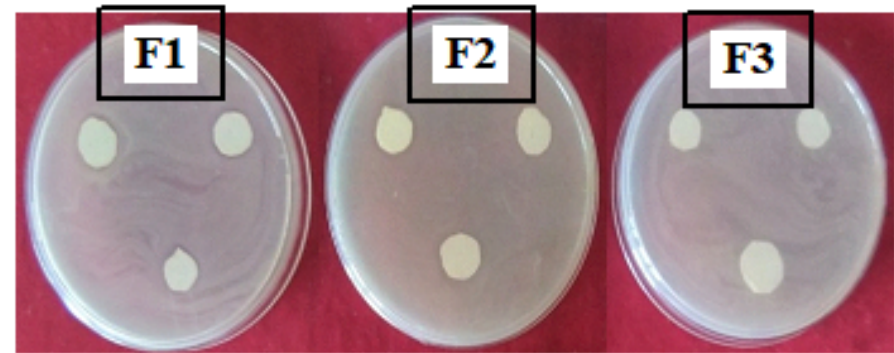


Figure 3

In vitro evaluation of herbicides against Xanthomonas oryzae pv. oryzae

A1: Cyhalofop-butyl (240 ppm); A2 (160 ppm); A3 (80 ppm); B1: (Cyhalofop-butyl + penoxsulam) (450 ppm); B2: (300 ppm); B3: (150 ppm); C1: Bispyribac-sodium (75 ppm); C2: (50 ppm); C3: (25 ppm); D1: Fenoxaprop-p-ethyl (180 ppm); D2: (120 ppm); D3 (60 ppm); E1: Carfentrazone-ethyl (60 ppm); E2: (40 ppm); E3: (20 ppm); F1: (Chlorimuron-ethyl + metsulfuron-methyl) (8 ppm); F2: (4 ppm); F3: (2 ppm); C: Control plate 


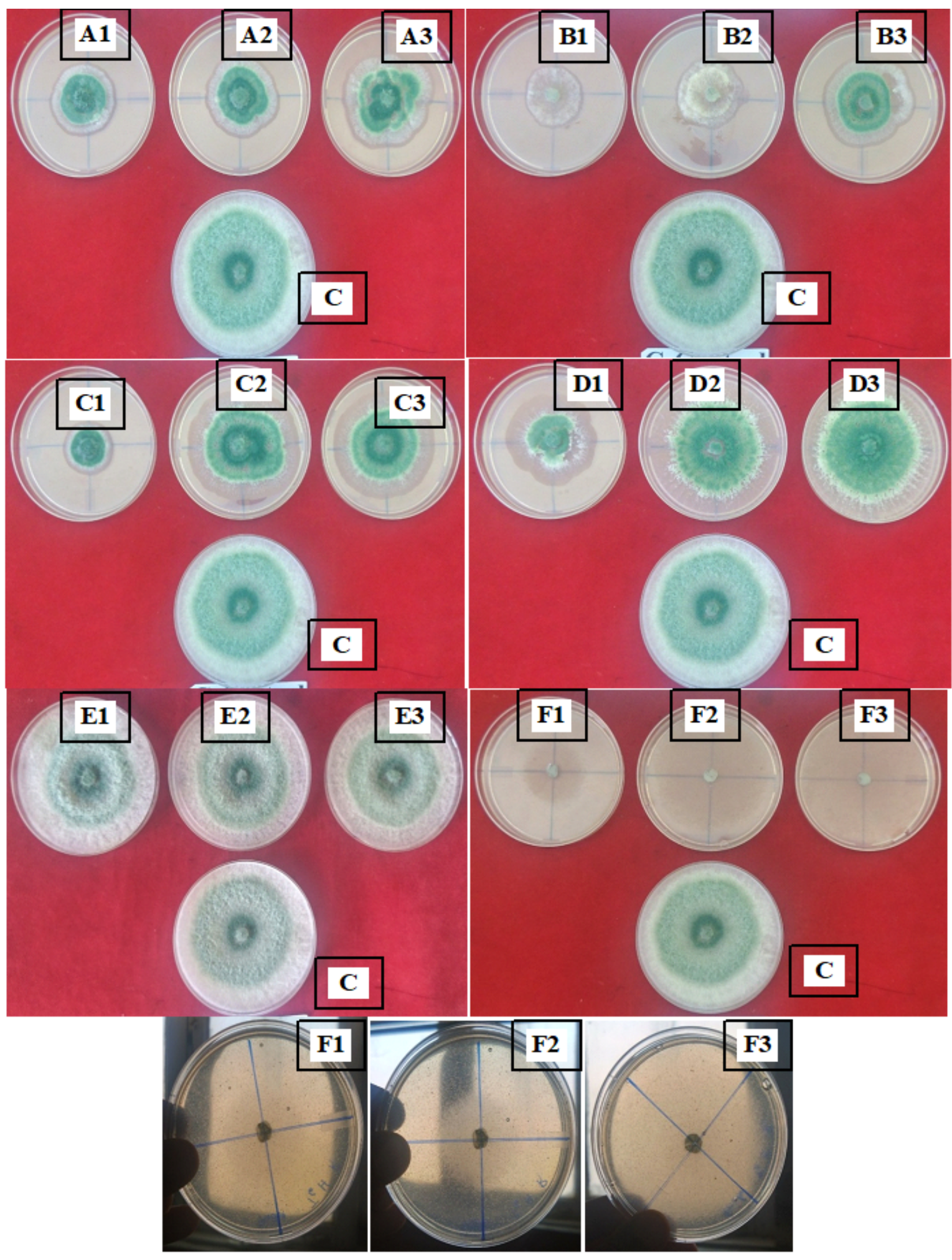

Figure 4

In vitro evaluation of herbicides against Trichoderma viride

A1: Cyhalofop-butyl (240 ppm); A2 (160 ppm); A3 (80 ppm); B1: (Cyhalofop-butyl + penoxsulam) (450 ppm); B2: (300 ppm); B3: (150 ppm); C1: Bispyribac-sodium (75 ppm); C2: (50 ppm); C3: (25 ppm); D1: Fenoxaprop-p-ethyl (180 ppm); D2: (120 ppm); D3 (60 ppm); E1: Carfentrazone-ethyl (60 ppm); E2: (40 
ppm); E3: (20 ppm); F1: (Chlorimuron-ethyl + metsulfuron-methyl) (8 ppm); F2: (4 ppm); F3: (2 ppm); C: Control plate
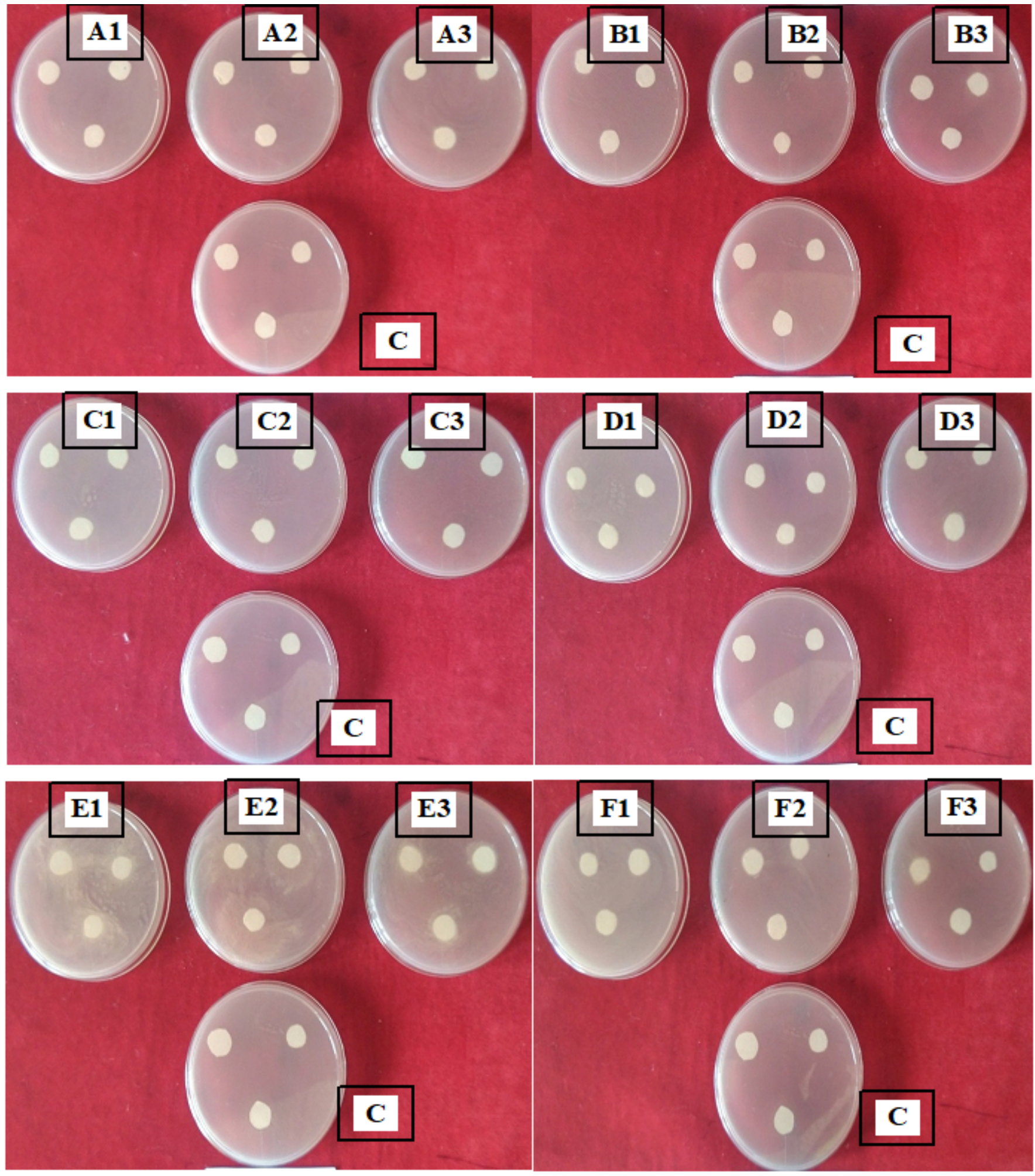

Figure 5 
A1: Cyhalofop-butyl (240 ppm); A2 (160 ppm); A3 (80 ppm); B1: (Cyhalofop-butyl + penoxsulam) (450 ppm); B2: (300 ppm); B3: (150 ppm); C1: Bispyribac-sodium (75 ppm); C2: (50 ppm); C3: (25 ppm); D1: Fenoxaprop-p-ethyl (180 ppm); D2: (120 ppm); D3 (60 ppm); E1: Carfentrazone-ethyl (60 ppm); E2: (40 ppm); E3: (20 ppm); F1: (Chlorimuron-ethyl + metsulfuron-methyl) (8 ppm); F2: (4 ppm); F3: (2 ppm); C: Control plate 